File 2746, 43(4) 1st Print

Avaiable online at www.banglajol.info

Bangladesh J. Sci. Ind. Res. 43(4), 571-580, 2008

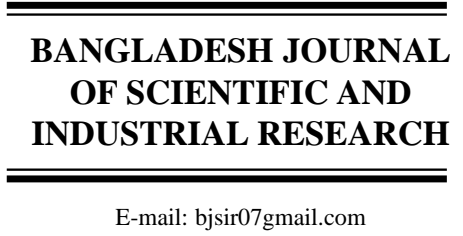

BCSIR

\title{
Influence of Sewage Sludge and Nitrogen Fertilization on Growth, Nutrient Content and Heavy Metal Uptake by Rice Straw
}

\author{
M.K. Kabir, S.M. Ullah, S. Jahan, M. Bashir Ullah and A.T.M.M. Kamal* \\ Department of Soil, Water and Environment, University of Dhaka, Dhaka-1000, Bangladesh
}

\begin{abstract}
A pot experiment was conducted to study the effects of sewage sludge and nitrogen fertilization on the growth, yield, nutrient and heavy metal uptake into rice straw (Oriza setiva L cv. BRRI dhan-36). There were five 5 treatments $\left(T_{0}, T_{1}, T_{2}, T_{3}\right.$ and $\left.T_{4}\right)$ consisting of 5 levels of sewage sludge $(0,60,120,200$ and $300 \mathrm{t} / \mathrm{ha}$ ) and 5 levels of nitrogen (280, 49, 35, 28 and $21 \mathrm{~kg} / \mathrm{ha})$. In the experiment the highest height of the rice plant (97.33 cm per plant) and number (55.00) of tillers per four plants were recorded with the treatment, 300 t/ha sewage sludge plus $21 \mathrm{~kg} / \mathrm{ha}$ nitrogen. The length of spikelet was significantly high in all treatments compared to the treatment, 300 t/ha sewage sludge plus $21 \mathrm{~kg} / \mathrm{ha}$ nitrogen. On the other hand, both the fresh and dry weight of rice straw was significantly high in the aforesaid treatment compared to the other treatments. The contents of $\mathrm{N}, \mathrm{K}, \mathrm{Na}, \mathrm{Ca}, \mathrm{Mg}, \mathrm{Fe}, \mathrm{Cu}, \mathrm{Zn}$ and $\mathrm{Pb}$ in rice straw increased significantly with increasing sewage sludge levels and were observed high at the treatment, 300 t/ha sewage sludge plus $21 \mathrm{~kg} / \mathrm{ha}$ nitrogen, but the amount of $\mathrm{P}$ and Mn uptake decreased significantly with increasing sewage sludge levels showing an antagonistic effect. Cr, Cd and Ni contents were below detectable level.
\end{abstract}

Key words: Sewage sludge, Fertilization, Rice straw, Nutrient, Heavy metal

\section{Introduction}

Bangladesh is a highly populated developing country with 0.13 acres land per capita (BBS 2006). Its agriculture plays a vital role in national economy since about $85 \%$ of the total population depends directly or indirectly on agriculture for their livelihood. But, unfortunately it possesses one of the lowest crop yield rates in the world, as majority of

* Corresponding author soils is deficient in plant nutrients, especially nitrogen like the other tropical and subtropical soils. Moreover, the organic matter content of Bangladesh's soil is below 1\% in about $60 \%$ cultivable land compared to an ideal minimum value of 4\% (Islam and Hussain, 1992). Farmers apply only about $160 \mathrm{~kg} /$ ha of nutrients (mainly N, P and K), while the estimated crop removal is approx- 
imately $280 \mathrm{~kg} / \mathrm{ha}$ (BARC 2005). This means a constant stress is on the soils.

Sewage sludge is the solid by-product of domestic and/or industrial wastewater treatment plant. Sewage sludge improves organic matter content, soil structure, aeration, water holding capacity, micronutrient status of soil and also increases microbial activities in soil (Bengston and Cornette 1973, and Sattar and Ahad 1988). It has been extensively used in cropped land in many countries of the world, especially Europe, America and some parts of Asia. But, this may cause a potential hazard, especially heavy metal pollution to soil if substantial amounts of $\mathrm{Cd}, \mathrm{Zn}, \mathrm{Ni}$ and other metals are not subtracted from the sludge (Adriano, 1986).

Approximately 54,750 tons of sewage sludge containing about 1,000 to 1,400 tons of nitrogen and 350 to 500 tons of phosphorus are produced per year in Dhaka city, Bangladesh (BARC, 1997). The sewage sludge of poor cities has a low content of nitrogen compared with European and Western cities because dwellers of these cities take less amount of protein in their diet (McCalla et al., 1977). Like poor cities, Dhaka City has open drainage system along with the subsurface sewage drainage system; thereby dust and other solid or semisolid materials easily get mixed into sewage sludge. Moreover, undesirable industrial sludge is also incorporated in the sewage pipe line. Later, they are carried to the sewage treatment plants. Thus, treated sewage sludge not only contains non-essential plant nutrients and heavy metals, but also possesses dust and other materials. Application of sewage sludge in agricultural land is not very extensive in Bangladesh. Application of sewage sludge to agricultural land may be a cheap source of nitrogen, phosphorus and organic matter to improve fertility and physical conditions of soil.

The objective of the experiment is to enumerate the combined effect of sewage sludge and nitrogen fertilization on growth, nutrient uptake and heavy metal contents in rice straw.

\section{Materials and Methods}

The soil collected for the experiment was silty clay in texture and belongs to Naraibag classified as Noncalcarious Dark-Grey Flood Plain soil in Bangladesh. Dry sewage sludge was collected from Dhaka WASA sewage treatment plant, Pagla, Dhaka, Bangladesh. The soil sample and sewage sludge sample were air-dried, ground and sieved through a $2 \mathrm{~mm}$ sieve for physical analyses as well as to grow rice. However, for chemical and physico-chemical analyses the soil sample and sewage sludge sample (air-dried and ground) were sieved through a $1 \mathrm{~mm}$ sieve and kept in plastic container. The relevant properties of the composite soil and sewage sludge are presented in Table I. 
Table I. Properties of soil sample and sewage sludge

\begin{tabular}{l|c|c}
\hline \multicolumn{1}{c|}{ Properties } & Values of soil sample & Values of sewage sludge \\
\hline Sand (\%) & 6.44 & - \\
Silt (\%) & 40.00 & - \\
Clay (\%) & 53.56 & - \\
pH & 6.10 & 5.8 \\
EC ( $\mu$ S) & 570 & 4900.00 \\
CEC (cmols/kg) & 17.05 & 27.75 \\
Organic matter (\%) & 3.10 & 10.15 \\
Available N (ppm) & 61.00 & 671.00 \\
Available P (ppm) & 14.00 & 25.00 \\
Total (N \%) & 0.08 & 1.42 \\
Total P (\%) & 0.40 & 0.85 \\
Total Na (\%) & 0.05 & 0.02 \\
Total K (\%) & 0.17 & 0.09 \\
Total Ca (\%) & 0.07 & 0.09 \\
Total Mg (\%) & 0.06 & 0.021 \\
Total Fe (\%) & 2.24 & 1.55 \\
Total Cu (\%) & 0.01 & 0.03 \\
Total Zn (\%) & 0.012 & 0.17 \\
Total Mn (\%) & 0.024 & 0.02 \\
Total Pb (ppm) & 50.00 & 100.00 \\
Total Cr (ppm) & 40.00 & 100.00 \\
Total Cd & 10.88 & 19.83 \\
Total Ni & 3.54 & 4.04 \\
Exchangeable Na (cmols/kg) & Below detectable range & Below detectable range \\
Exchangeable K (cmols/kg) & Below detectable range & 1.85 \\
Exchangeable Ca (cmols/kg) & 1.63 & \\
Exchangeable Mg (cmols/kg) & 0.38 & \\
\hline & & \\
\hline
\end{tabular}

BRRI dhan-36, a high yielding variety of rice (Oriza setiva L.) was grown in pots in boro season to study the effects of combined nitrogen-sewage sludge on it. The experiment was conducted with 5 treatments $\left(\mathrm{T}_{0}\right.$,
$\mathrm{T}_{1}, \mathrm{~T}_{2}, \mathrm{~T}_{3}$ and $\mathrm{T}_{4}$ designated by $\mathrm{SS}_{0} \mathrm{~N}_{280}$, $\mathrm{SS}_{60} \mathrm{~N}_{49}, \mathrm{SS}_{120} \mathrm{~N}_{35}, \mathrm{SS}_{200} \mathrm{~N}_{28}$, and $\mathrm{SS}_{300} \mathrm{~N}_{21}$, respectively) consisting of 5 levels of sewage sludge $(0,60,120,200$ and $300 \mathrm{t} / \mathrm{ha}$ designated by $\mathrm{SS}_{0}, \mathrm{SS}_{60}, \mathrm{SS}_{120}, \mathrm{SS}_{200}$ and 
$\mathrm{SS}_{300}$, respectively) and 5 levels of nitrogen (280, 49, 35, 28 and $21 \mathrm{~kg} / \mathrm{ha}$ designated by $\mathrm{N}_{280}, \mathrm{~N}_{49}, \mathrm{~N}_{35}, \mathrm{~N}_{28}$ and $\mathrm{N}_{21}$, respectively). Nitrogen was applied in the form of urea fertilizer.

Six kg of air-dried soil was mixed with sewage sludge according to the treatments and put in a pot. Basal doses of phosphorus and potassium were applied in the form of TSP and MP at $200 \mathrm{~kg} \mathrm{P}_{2} \mathrm{O}_{5} / \mathrm{ha}$ and $200 \mathrm{~kg}$ $\mathrm{K}_{2} \mathrm{O} / \mathrm{ha}$, respectively, during the final pot preparation on the day of transplanting. After 5 days of transplantation of rice seedling half dose of $\mathrm{N}$ was applied in the treatment $\mathrm{T}_{0}$ and full dose of $\mathrm{N}$ to the treatment $\mathrm{T}_{1}, \mathrm{~T}_{2}, \mathrm{~T}_{3}$ and $\mathrm{T}_{4}$. One fourth dose of $\mathrm{N}$ was applied to $\mathrm{T}_{0}$ after 55 days of transplantation and the rest of one fourth was applied after 100 days of transplantation. Eight uniform sized rice seedlings (40 days old) were transplanted (2 seedlings/hill) in each pot, but after 15 days only the best four were allowed to grow. During the growing period, pots were irrigated properly with normal tap water and intercultural operations were done, whenever necessary. The experiment was laid out in a completely randomized design with three replications for each treatment.

The height of rice plant (cm/plant) and number of tiller per four plants were recorded at 30, 60, 90 and 130 days after transplantation (DAT). Rice plants were harvested at full maturity after 130 days of transplantation.
The length of spikelet (cm/plant) was recorded after harvest. The straw was separated from grain and dried in the sun. The fresh (after dried in the sun) and dry weight (after oven-dried at $70^{\circ} \mathrm{C}$ for 3 days) of straw were recorded on per pot basis.

Total nitrogen content of rice straw was determined by Micro-Kjeldhal's method following $\mathrm{H}_{2} \mathrm{SO}_{4}$ digestion and stream distillation with $40 \% \mathrm{NaOH}$ (Jackson, 1973). The total contents of $\mathrm{P}, \mathrm{Na}, \mathrm{K}, \mathrm{Ca}, \mathrm{Mg}, \mathrm{Fe}, \mathrm{Zn}$, $\mathrm{Cu}, \mathrm{Mn}, \mathrm{Pb}, \mathrm{Cr}, \mathrm{Cd}$, and $\mathrm{Ni}$ in rice straw were determined after wet digestion of straw samples in $\mathrm{HNO}_{3}-\mathrm{HClO}_{4}$ acid (5:1) mixture. Gallenkamp Flame Photometer analyzed the extract for total sodium and potassium at 589 and $767 \mathrm{~nm}$, respectively (Jackson, 1973). Calcium and magnesium were measured by atomic absorption spectrophotometer (Perkin Elmer, 31100) at 422.7 and 285.5 nm, respectively (Jackson, 1973). The total phosphorus content of straw was determined colorimetrically using a Chemito Visible Spectrophotometer, after developing the yellow color and the intensity of the color was measured at $470 \mathrm{~nm}$ wavelength (Jackson, 1973). The metals contents of $\mathrm{Fe}, \mathrm{Zn}, \mathrm{Cu}$, $\mathrm{Mn}, \mathrm{Pb}, \mathrm{Cd}, \mathrm{Cr}$ and $\mathrm{Ni}$ in rice straw were analyzed in the extract by using atomic absorption spectrometer (Perkin Elmer, 3110) (Jackson, 1973). Collected results were statistically analyzed using Duncan's New Multiple Range Test (DMRT) (Gomez and Gomez, 1976). 


\section{Results and Discussion}

The variation of height of rice plant was non-significant (ns) in the different levels of treatment at DAT 30 and DAT 60 (Table II). The highest height of rice plant (97.33 $\mathrm{cm} /$ plant) was obtained at DAT 130 in the treatment $\mathrm{T}_{4}$ (Table II), but it has slight different from the treatment $T_{3}$, although differed significantly from the other treatments $\left(\mathrm{T}_{0}, \mathrm{~T}_{1}\right.$ and $\left.\mathrm{T}_{2}\right)$. There was no significant difference between the treatments of $\mathrm{T}_{0}$ and $\mathrm{T}_{1}$, and $\mathrm{T}_{1}$ and $\mathrm{T}_{2}$. the treatment (Noggle and Fritz 1976, and Mengel and Kirkby, 1996). The length of spikelet was recorded after harvest (Table III). No significant difference in the length of spikelet was observed among the treatments $-\mathrm{T}_{0}, \mathrm{~T}_{1}, \mathrm{~T}_{2}$ and $\mathrm{T}_{3}$, but at treatment $\mathrm{T}_{4}$ the length of spikelet decreased significantly compared to the other treatments.

The maximum fresh weight (135.33 g/pot) and dry weight $(75.74 \mathrm{~g} / \mathrm{pot})$ of rice straw were obtained from the treatment $T_{4}$ (Table III). At the treatment $T_{4}$, both fresh and dry

Table II: Effect of sewage sludge on growth characteristics of straw of rice.

\begin{tabular}{c|c|c|c|c|c|c|c|c|c}
\hline \multicolumn{2}{c|}{ Treatments } & \multicolumn{4}{|c|}{ Height of plants (cm/plant) } & \multicolumn{3}{c}{ Number of tiller/ four plants } \\
\cline { 3 - 10 } \multicolumn{2}{c|}{} & 30 DAT & 60 DAT & 90 DAT & 130 DAT & 30 DAT & 60 DAT & 90 DAT & 130 DAT \\
\hline $\mathrm{T}_{0}$ & $\mathrm{SS}_{0} \mathrm{~N}_{280}$ & $22.20 \mathrm{~ns}$ & $33.90 \mathrm{~ns}$ & $81.33 \mathrm{~b}$ & $86.00 \mathrm{c}$ & $5.33 \mathrm{c}$ & $17.33 \mathrm{~ns}$ & $31.00 \mathrm{~b}$ & $35.67 \mathrm{~b}$ \\
$\mathrm{~T}_{1}$ & $\mathrm{SS}_{60} \mathrm{~N}_{49}$ & $23.70 \mathrm{~ns}$ & $34.83 \mathrm{~ns}$ & $80.33 \mathrm{~b}$ & $87.00 \mathrm{bc}$ & $6.00 \mathrm{c}$ & $19.33 \mathrm{~ns}$ & $34.00 \mathrm{~b}$ & $38.33 \mathrm{~b}$ \\
$\mathrm{~T}_{2}$ & $\mathrm{SS}_{120} \mathrm{~N}_{35}$ & $23.23 \mathrm{~ns}$ & $37.50 \mathrm{~ns}$ & $83.00 \mathrm{a}$ & $89.33 \mathrm{~b}$ & $6.67 \mathrm{bc}$ & $20.00 \mathrm{~ns}$ & $34.60 \mathrm{~b}$ & $39.00 \mathrm{~b}$ \\
$\mathrm{~T}_{3}$ & $\mathrm{SS}_{200} \mathrm{~N}_{28}$ & $25.63 \mathrm{~ns}$ & $38.20 \mathrm{~ns}$ & $84.00 \mathrm{a}$ & $96.00 \mathrm{a}$ & $8.33 \mathrm{ab}$ & $21.33 \mathrm{~ns}$ & $40.00 \mathrm{ab}$ & $44.00 \mathrm{~b}$ \\
$\mathrm{~T}_{4}$ & $\mathrm{SS}_{300} \mathrm{~N}_{21}$ & $27.77 \mathrm{~ns}$ & $39.77 \mathrm{~ns}$ & $81.00 \mathrm{~b}$ & $97.33 \mathrm{a}$ & $9.67 \mathrm{a}$ & $31.67 \mathrm{~ns}$ & $52.33 \mathrm{a}$ & $55.00 \mathrm{a}$ \\
\hline
\end{tabular}

ns = Non-significant, Means followed by the same letter(s) are not significantly

defferent at 5\% level of DMRT

The maximum number of tiller/ four plants after 130 days of transplantation were recorded at treatment $\mathrm{T}_{4}$. It differed significantly from other treatments, but the treatment $\mathrm{T}_{0}, \mathrm{~T}_{1}, \mathrm{~T}_{2}$ and $\mathrm{T}_{3}$ did not differ significantly from one another (Table II). The higher vegetative growth of rice straw (i.e., height and number of tiller) in the elevated sewage sludge treated plant was occurred owing to higher nitrogen fertilization from weight of rice straw was significantly higher than the other treatments. On the other hand, treatments $\mathrm{T}_{0}, \mathrm{~T}_{1}, \mathrm{~T}_{2}$ and $\mathrm{T}_{3}$ did not differ significantly from each another. High rate of mineralization of nitrogen from sewage sludge applications encouraged excessive vegetative growth of rice and other plant parts and hence, fresh and dry weight. 
Table III: Effect of sewage sludge on spikelet length and straw weight of rice straw.

\begin{tabular}{c|c|c|c|c}
\hline \multirow{2}{*}{ Treatments } & \multirow{2}{*}{$\begin{array}{c}\text { Length of spiketel } \\
\text { (cm/plant) }\end{array}$} & \multicolumn{2}{c}{ Weight of straw (g/pot) } \\
\cline { 3 - 5 } \multicolumn{2}{c|}{} & & Fresh & Dry \\
\hline $\mathrm{T}_{0}$ & $\mathrm{SS}_{0} \mathrm{~N}_{280}$ & $25.00 \mathrm{a}$ & $89.67 \mathrm{~b}$ & $44.08 \mathrm{~b}$ \\
$\mathrm{~T}_{1}$ & $\mathrm{SS}_{60} \mathrm{~N}_{49}$ & $24.17 \mathrm{a}$ & $90.00 \mathrm{~b}$ & $44.80 \mathrm{~b}$ \\
$\mathrm{~T}_{2}$ & $\mathrm{SS}_{120} \mathrm{~N}_{35}$ & $24.80 \mathrm{a}$ & $96.33 \mathrm{~b}$ & $48.20 \mathrm{~b}$ \\
$\mathrm{~T}_{3}$ & $\mathrm{SS}_{200} \mathrm{~N}_{28}$ & $23.05 \mathrm{a}$ & $97.00 \mathrm{~b}$ & $51.48 \mathrm{~b}$ \\
$\mathrm{~T}_{4}$ & $\mathrm{SS}_{300} \mathrm{~N}_{21}$ & $22.20 \mathrm{~b}$ & $135.33 \mathrm{a}$ & $75.74 \mathrm{a}$ \\
\hline
\end{tabular}

Means followed by the same letter(s) are not significantly defferent at 5\% level of DMRT

The content of nitrogen in the straw of rice ranged from 0.84 to $1.06 \%$ (Table IV). At the treatment $\mathrm{T}_{0}$ (only nitrogen applied as urea), nitrogen content was minimum, but increased gradually at higher rates of sewage sludge (both increased rates of sewage sludge and decreased rates of nitrogen applied) application. There was no significant difference among the treatments $\mathrm{T}_{0}, \mathrm{~T}_{1}$ and $\mathrm{T}_{2}$. However, significant difference persisted between the aforesaid treatments and treatments $-\mathrm{T}_{3}$ and $\mathrm{T}_{4}$. This might be due to the increased rate of mineralization of nitrogen from sewage sludge. In such kind of experiments, the increased content of nitrogen in rice was also observed by Tamura et al. (1988) and Gupta et al. (1993). Phosphorus content was high in treatments $\mathrm{T}_{0}$, but no difference was found with treatment $\mathrm{T}_{1}$ (Table IV). Moreover, no significant difference was observed among the treatments $T_{2}, T_{3}$ to $T_{4}$, but they were significantly different from the treatments $T_{0}$ and $T_{1}$. Application of sewage sludge reduced the uptake of phosphorous content in the treated rice plant. This might have caused due to low rate of phosphorus mineralization from the applied sewage sludge, or fixation of phosphorus by dust particles incorporated within sewage sludge or loss of phosphorus with de-watering from the sewage treatment plant. Similar result was also observed by Hiroki and Fujii (1984). Both potassium and sodium contents in rice straw differed significantly from one another in most of the treatments, however, no significant difference was observed between treatments $T_{3}$ and $T_{4}$. In general $\mathrm{K}$ has antagonistic effect on $\mathrm{Na}$ (He and Cramer, 1992) but in this experiment sewage sludge enhanced the uptake of both $\mathrm{K}$ and $\mathrm{Na}$. This might be happened due to the presence of low amount of $\mathrm{K}$ in sewage sludge which was in available form. As a result, more Na was absorbed by rice plants to fulfill the demand of $\mathrm{K}$ and also to ion balance. Increased rates of sewage sludge application in the experimental soil enhanced the uptake of calcium and magnesium by rice straw (Table IV). This higher accumulation of both $\mathrm{Ca}(0.877 \%)$ and $\mathrm{Mg}$ 
Table IV: Effect of sewage sludge on mineral nutrient content of rice straw

\begin{tabular}{c|c|c|c|c|c|c|c}
\hline \multicolumn{2}{c|}{ Treatments } & \multicolumn{6}{c}{ Mineral nutrient content (\%) (dry weight basis) } \\
\cline { 3 - 8 } \multicolumn{2}{c|}{} & $\mathrm{N}$ & $\mathrm{P}$ & $\mathrm{K}$ & $\mathrm{Na}$ & $\mathrm{Ca}$ & $\mathrm{Mg}$ \\
\hline $\mathrm{T}_{0}$ & $\mathrm{SS}_{0} \mathrm{~N}_{280}$ & $0.84 \mathrm{~b}$ & $0.425 \mathrm{a}$ & $1.25 \mathrm{~d}$ & $0.22 \mathrm{~d}$ & $0.620 \mathrm{c}$ & $0.42 \mathrm{~b}$ \\
$\mathrm{~T}_{1}$ & $\mathrm{SS}_{60} \mathrm{~N}_{49}$ & $0.85 \mathrm{~b}$ & $0.421 \mathrm{a}$ & $1.40 \mathrm{c}$ & $0.30 \mathrm{c}$ & $0.650 \mathrm{c}$ & $0.43 \mathrm{~b}$ \\
$\mathrm{~T}_{2}$ & $\mathrm{SS}_{120} \mathrm{~N}_{35}$ & $0.86 \mathrm{~b}$ & $0.300 \mathrm{~b}$ & $1.45 \mathrm{~b}$ & $0.36 \mathrm{~b}$ & $0.770 \mathrm{~b}$ & $0.45 \mathrm{ab}$ \\
$\mathrm{T}_{3}$ & $\mathrm{SS}_{200} \mathrm{~N}_{28}$ & $1.04 \mathrm{a}$ & $0.298 \mathrm{~b}$ & $1.60 \mathrm{a}$ & $0.41 \mathrm{a}$ & $0.776 \mathrm{~b}$ & $0.47 \mathrm{ab}$ \\
$\mathrm{T}_{4}$ & $\mathrm{SS}_{300} \mathrm{~N}_{21}$ & $1.06 \mathrm{a}$ & $0.290 \mathrm{~b}$ & $1.65 \mathrm{a}$ & $0.45 \mathrm{a}$ & $0.877 \mathrm{a}$ & $0.50 \mathrm{a}$ \\
\hline
\end{tabular}

Means followed by the same letter(s) are not significantly defferent at 5\% level of DMRT

(0.50\%) may be attributed to the presence of high amount of $\mathrm{Ca}$ and $\mathrm{Mg}$ in the sewage sludge.

Combined sewage sludge and nitrogen application influenced the uptake of heavy metals in the straw of rice plant (Table V). With increasing sewage sludge application, the contents of iron, copper, zinc and lead were the highest in the treatment $\mathrm{T}_{4}$, while the treatment $T_{0}$ exhibited the lowest uptake of these elements having no significant difference with the treatment $T_{1}$. There was a significant difference in the uptake of $\mathrm{Fe}$ (0.065, 0.071 and 0.080\%) and $\mathrm{Cu}$ (44.00, 55.00 and $66.67 \mathrm{ppm}$ ) in rice straw among the treatments $T_{2}, T_{3}$ and $T_{4}$ (Table $V$ ). In the case of Zn-uptake no significant difference was found between the treatments $T_{3}$ and $T_{4}$. Likewise, treatments $\mathrm{T}_{2}$ and $\mathrm{T}_{3}$ had no significant difference in $\mathrm{Pb}$ uptake. The application of sewage sludge containing $\mathrm{Fe}, \mathrm{Cu}$, $\mathrm{Zn}$ and $\mathrm{Pb}$ may enhance their uptake in the rice straw. Similar result was found by Prasad et al. (1989) and Paulraj and Ramulu
(1994). Prasad et al. (1989) observed that iron-enriched organic wastes application increased uptake of $\mathrm{Fe}$ in rice plants. $\mathrm{Fe}, \mathrm{Cu}$, $\mathrm{Zn}$ and $\mathrm{Pb}$ uptake increased in various vegetables due to presence of these elements in sewage sludge (Paulraj and Ramulu, 1994). Sewage sludge applications increased the concentration of $\mathrm{Cu}$ and $\mathrm{Zn}$ in the shoots of corn (Mullins et al. 1986), in the leaves of maize and bean, and also in the pepper stem (Muchuweti et. al., 2006) as sludge derived from domestic source contained high amounts of $\mathrm{Cu}$ and $\mathrm{Zn}$.

Manganese content in rice straw decreased significantly with increasing sewage sludge application (Table V); however no significant difference was found between the treatments - $\mathrm{T}_{0}$ and $\mathrm{T}_{1}$ and $\mathrm{T}_{2}$ and $\mathrm{T}_{3}$. The decreased content of $\mathrm{Mn}$ in rice straw may be out due to the complexation or chelation of $\mathrm{Mn}$ with humic substances present in the applied sewage sludge and thereby, reducing the availability of Mn to rice plants. Reduced low uptake of Mn was reported in sewage 
Table V: Effect of sewage sludge on heavy metal content of rice straw.

\begin{tabular}{c|c|c|c|c|c|c|c|c|c}
\hline \multirow{2}{*}{ Treatments } & \multicolumn{7}{c}{ Heavy metal content (dry weight basis) } \\
\cline { 3 - 10 } \multicolumn{2}{c|}{} & $\mathrm{Fe}(\%)$ & $\begin{array}{c}\mathrm{Cu} \\
(\mathrm{ppm})\end{array}$ & $\begin{array}{c}\mathrm{Mn} \\
(\mathrm{ppm})\end{array}$ & $\begin{array}{c}\mathrm{Zn} \\
(\mathrm{ppm})\end{array}$ & $\begin{array}{c}\mathrm{Pb} \\
(\mathrm{ppm})\end{array}$ & $\begin{array}{c}\mathrm{Cr} \\
(\mathrm{ppm})\end{array}$ & $\begin{array}{c}\mathrm{Cd} \\
(\mathrm{ppm})\end{array}$ & $\begin{array}{c}\mathrm{Ni} \\
(\mathrm{ppm})\end{array}$ \\
\hline $\mathrm{T}_{0}$ & $\mathrm{SS}_{0} \mathrm{~N}_{280}$ & $0.057 \mathrm{~d}$ & $34.00 \mathrm{~d}$ & $266.67 \mathrm{a}$ & $110.00 \mathrm{c}$ & $11.67 \mathrm{c}$ & - & - & - \\
$\mathrm{T}_{1}$ & $\mathrm{SS}_{0} \mathrm{~N}_{49}$ & $0.059 \mathrm{~d}$ & $40.00 \mathrm{~cd}$ & $250.00 \mathrm{a}$ & $133.33 \mathrm{c}$ & $16.67 \mathrm{bc}$ & - & - & - \\
$\mathrm{T}_{2}$ & $\mathrm{SS}_{012} \mathrm{~N}_{35}$ & $0.065 \mathrm{c}$ & $44.00 \mathrm{c}$ & $183.33 \mathrm{~b}$ & $190.33 \mathrm{~b}$ & $20.00 \mathrm{~b}$ & - & - & - \\
$\mathrm{T}_{3}$ & $\mathrm{SS}_{200} \mathrm{~N}_{28}$ & $0.071 \mathrm{~b}$ & $55.00 \mathrm{~b}$ & $180.00 \mathrm{~b}$ & $260.00 \mathrm{a}$ & $22.00 \mathrm{~b}$ & - & - & - \\
$\mathrm{T}_{4}$ & $\mathrm{SS}_{300} \mathrm{~N}_{21}$ & $0.080 \mathrm{a}$ & $66.67 \mathrm{a}$ & $33.33 \mathrm{c}$ & $296.67 \mathrm{a}$ & $33.33 \mathrm{a}$ & - & - & - \\
\hline
\end{tabular}

Means followed by the same letter(s) are not significantly defferent at 5\% level of DMR

sludge added than in inorganic fertilizer applied tomatoes (Paulraj and Ramulu, 1994). No bio-accumulation of $\mathrm{Cr}$, Cd and $\mathrm{Ni}$ was observed in the sewage sludge treated rice straw as they were below detection limit, and this might be due to low content of these heavy metals in the sewage sludge (Table V).

\section{Conclusions}

The paramount yield response of rice straw was acquired with the treatment $T_{4}$ $\mathrm{SS}_{300} \mathrm{~N}_{21}$ ), where 300 tons of sewage sludge per hectare plus $21 \mathrm{~kg}$ of nitrogen per hectare were added. The macronutrient contents of $\mathrm{N}, \mathrm{K}, \mathrm{Na}, \mathrm{Ca}$ and $\mathrm{Mg}$ as well as the other metal contents of $\mathrm{Fe}, \mathrm{Cu}, \mathrm{Zn}$ and $\mathrm{Pd}$ were heighest in this treatment $\left(\mathrm{T}_{4}\right)$. Thus, sewage sludge fertilization might be a valuable source of essential macro- and micro nutrient elements, if the heavy metals content could be minimum. Recycling of plant nutrients from sewage sludge can contribute to the saving of natural resources only if the demands of soil and environmental protection are fully satisfied.

\section{References}

Adriano, D.C. (1986) Trace elements in the terrestrial environment. Springer-Vela, New York.

BARC. (2005) Fertilizer recommendation guide2005, Bangladesh Agricultural Research Council (BARC), BARC publishing section, Farm gate, Dhaka, Bangladesh.

BARC. (1997) Fertilizer recommendation guide, Soil and irrigation publication No. 13, Bangladesh Agricultural Research Council (BARC), BARC publishing section, Farm gate, Dhaka, Bangladesh.

BBS. (2006) Statistical Pocketbook of Bangladesh, 2005, Planning Division, 
Ministry of Planning, Dhaka, Bangladesh.

Bengston, G.W. Cornette, J.J. (1973) Disposal of composted municipal waste in plantation of young slash pine: effects on soil and trees. J. Environ. Qual. 2: 441-444.

Gomez, K.A. Gomez, A.A. (1976) Statistical procedures for agricultural research withemphasis on rice. The International Rice Research Institute, Philippines, pp. 10-53.

Gupta, A.P. Narweal, R.P. Antil, R.S. (1993) Effect of different levels of phosphorus and sewage sludge on wheat. J. Indian Soci. Soil. Sci. 41 (2):304-307.

He, T. Cramer, G.R. (1992) Growth and mineral nutrition of six rapid cycling Brassica species in response to seawater salinity. Plant and Soil 193: 285-294.

Hiroki, M. Fujii, K. (1984) Growth and element content of rice cultivated on paddy soil with application of sewage sludge. Research report, National Institute of Environmental Studies, No. 68.17-29.

Islam, N. Hossain, S.M.A. (1992) Drought, concept of agronomic manipulation in Bangladesh. Proceeding of First Biennial conference of the Crop Science Society of Bangladesh held at BAU during January 18-20, pp. 178.
Jackson, M.L. (1973) Soil chemical analysis. (Prentice Hall of India Private Limited, New Delhi), pp. 324-416.

McCalla, T.M. Peterson, J.R. Lue-Hing, C. (1977) Properties of agricultural and municipal wastes. In: Soils for management of organic wastes and waste water. Elliolt, L.F. and Stevenson, F.J. (Eds.) (Madison, WI: Soil Sci. Soc. Amer.), pp. 11-43.

Mengel, K Kirkby, E.A. (1996) Principles of plant nutrition. 4th Ed. (Panama Publishing Corporation, New Delhi), pp. 87-119.

Muchuweti, M. Birkett, J.W. Chinyanga, E. Zvauya, R. Scrimshaw, M.D. Lester, J.N. (2006) Heavy metal content of vegetables irrigated with mixtures of wastewater and sewage sludge in Zimbabwe: Implications for human health. Agriculture, ecosystem and Environment 112:41-48.

Mullins, G.L. Sommers, L.E. Barber, S.A. (1986) Modeling the plant uptake of cadmium and zinc from soil treated with sewage sludge. J. Am. Soc. Soil. Sci. 50: 1245-1250.

Noggle, G.R. Fritz, G.J. (1976) Introductory plant physiology. (Prentice-Hall, Inc. Englewood Cliffs, New Jersey), pp. 233-302.

Paulraj, C. Ramulu, U.S.S. (1994) Effects of soil application of low levels of urban sewage 
sludge on the uptake of nutrients and yields of certain vegetables. J. Indian Soc. Soil. Sci. 42(3):485-487.

Prasad, B. Prasad, J. Prasad, R. (1989) Influence of iron-enriched organic wastes on crop yield and iron nutrition of crop in calcareous soil. Indian J. Agric. Sci. 59(6): 359364.

Sattar, M.A. Ahad, M.A. (1988) Function/properties of organic matter. In: Krishi Mrittika Bigghyan (in Bengali Ed), Sattar, A. (Ali Press, Mymensingh, Bangladesh), pp. 86.
Tamura, Y. Takeuchi, M. Seino, K. (1988) Effects of application of sewage sludge compost on paddy rice growing in cool regions of Japan. Bulletin of Tohoku national agricultural experiment station. Japan TohokuNogyo Shikenjo Kenkyu Hokohu, No. 78:193-153.

Received :February, 13, 2008;

Accepted : July, 23, 2008. 